\title{
LEAF GEOMETRIC MORPHOMETRICS AMONG POPULATIONS OF Dalbergia ecastaphyllum (L.) TAUB.
}

\author{
MORFOMETRIA GEOMÉTRICA FOLIAR ENTRE POPULAÇÕES DE \\ Dalbergia ecastaphyllum (L.) Taub. DO BRASIL
}

\section{Daniel Vieira de MORAIS ${ }^{1}$; Lorena Andrade NUNES ${ }^{2}$; Vandira Pereira da MATA Maria Angélica Pereira de Carvalho COSTA ${ }^{4}$; Geni da Silva SODRÉ 5 ; Carlos Alfredo Lopes de CARVALHO}

1. Doutorando do Programa de Pós-Graduação em Ciências do Centro de Energia Nuclear da Universidade de São Paulo - USP, Piracicaba, SP, Brasil; 2. Pós - doutoranda do Programa de Pós-Graduação em Enfermagem e Saúde da Universidade Estadual do Sudoeste da Bahia - UESB, Jequié, BA, Brasil; 3. Mestre em Ciências Agrárias, Universidade Federal do Recôncavo da Bahia - UFRB, Cruz das Almas, BA; 4. Professor Associado 1 da Universidade Federal do Recôncavo da Bahia - UFRB, Cruz das Almas, BA, Brasil. 5. Professor Titular da Universidade Federal do Recôncavo da Bahia - UFRB, Cruz das Almas, BA, Brasil. engagromorais@gmail.com

\begin{abstract}
Leaves are plant structures that express important traits of the environment where they live. Leaf description has allowed identification of plant species as well as investigation of abiotic factors effects on their development, such as gases, light, temperature, and herbivory. This study described populations of Dalbergia ecastaphyllum through leaf geometric morphometrics in Brazil. We evaluated 200 leaves from four populations. The principal component analysis (PCA) showed that the first four principal components were responsible for $97.81 \%$ of variation. The non-parametric multivariate analysis of variance (NPMANOVA) indicated significant difference between samples $(\mathrm{p}=0.0001)$. The Mentel test showed no correlation between geographical distances and shape. The canonical variate analysis (CVA) indicated that the first two variables were responsible for $96.77 \%$ of total variation, while the cross-validation test showed an average of $83.33 \%$. D. ecastaphyllum leaves are elliptical and ovate.
\end{abstract}

KEYWORDS: Shape. Dalbergia ecastaphyllum. Morphometric variation. Fabaceae.

\section{INTRODUCTION}

Dalbergia ecastaphyllum (Fabaceae) is native to Brazil; however, there are records of this species along the eastern American and western African coasts (CARVALHO, 1997; OLIVEIRA; CORTEZ, 2015). In Brazil, D. ecastaphyllum is found from the Amazon (northern region) to the Atlantic Rainforest (southern region) (LIMA, 2017).

Commonly known as "rabo-de-bugio" in Brazil, D. ecastaphyllum is considered a typical species of mangrove or flooded areas (CARVALHO, 1997; REYS; CANTILLO, 2004) and can be found in sandy soils thus helping in sand dune stabilization (GÜTTLER, 2007). Its vegetative habit is also quite variable, that is, scandent or semiprostrated in flooded areas, or shrubby-to-sapling in dunes (CARVALHO, 1997; REYS; CANTILLO, 2004; MARQUES, 2005).

The development pattern of $D$. ecastaphyllum is variable in its predominant habitats. Boeger et al. (2008) emphasized that environmental factors commonly affect plant structure and plant morphology and anatomy express the changes caused by this interaction. Thus, studies on the description of plant species and their interaction with the environment have great relevance.

D. ecastaphyllum is considered the botanical origin of red propolis in northeastern Brazil. Its phenolic compounds-enriched resinous substance contains antimicrobial, antioxidant, and antitumoral activities (CASTRO et al., 2009; FROZZA et al., 2013). Therefore, studies on its bioprospecting are frequent.

Among plant structures, leaves are the best indicators of environmental effects on plant development. Thus, leaf description has great relevance for plant identification and use, as well as for understanding plant interaction with the environment (PIRES et al., 2015). Leaves are structures mostly used for the identification of $D$. ecastaphyllum in the field.

Geometric morphometrics has been widely used to evaluate plant species in several aspects namely evolution (KLINGENBERG et al. 2012), taxonomy (CONESA et al., 2012), and genetic diversity (SAVRIAMA et al., 2012; STRELIN et al., 2013). This technique has been used to evaluate leaf changes through the analysis of relative landmark positions and sets of points in approximating (curves) surfaces and quantifying 
size and shape. Geometric morphometrics allows the direct study of object shapes by viewing thin plate-splines thus enabling the description of differences between shapes and estimation of the variance-covariance matrix in particular traits (BOOKSTEIN, 1991; DRYDEN; MARDIA, 2016). This technique therefore greatly contributes to plant studies.

Although D. ecastaphyllum plays an important ecological role in the environment, to date, no studies have correlated its morphological aspects with environmental influence. This study described for the first time populations of Dalbergia ecastaphyllum through leaf geometric morphometrics, contributing to a better understanding of the species ecological aspects.

\section{MATERIAL AND METHODS}

\section{Study site and populations}

Four populations of D. ecastaphyllum were sampled from the coastal region of Bahia State,
Brazil, on beach edges, rivers, mangroves, and hypersaline tidal flats (locally known as "apicuns"), far from urban areas, in the Metropolitan Region of Salvador (Vera Cruz and Itaparica municipalities) and on the southern coast (Ilhéus and Canavieiras municipalities) (Table 1). These regions belong to the Atlantic Rainforest and form varied ecosystems (MDA, 2010).

The Metropolitan Region of Salvador has hot and humid weather, with an average annual temperature of $25{ }^{\circ} \mathrm{C}$, and includes the Bay of All Saints, the world's second largest bay, a tourist attraction with environmental importance to the region.

The southern coast has regular rainfall throughout the year. Average temperatures range from 22 to $25{ }^{\circ} \mathrm{C}$, with humid-to-subhumid weather. The coast has important mangrove and sandbank systems, which receive maritime influence with low-fertility sandy soils, special conditions for an ideal ecosystem for the development of several species (MDA, 2010).

Table 1. Geographic data of four municipalities for sampling of Dalbergia ecastaphyllum in Bahia State.

\begin{tabular}{llcl}
\hline \multirow{2}{*}{ Site } & \multicolumn{1}{c}{ Location } & \multicolumn{2}{c}{ Coordinates } \\
\cline { 3 - 4 } Itaparica & Metropolitan & $12^{\circ} 53^{\prime} 18^{\prime \prime} \mathrm{S}$ & Longitude \\
Vera Cruz & Metropolitan & $13^{\circ} 5^{\prime} 60^{\prime \prime} \mathrm{S}$ & $38^{\circ} 40^{\prime} 43^{\prime \prime} \mathrm{W}$ \\
Canavieiras & Southern Coast & $14^{\circ} 47^{\prime} 36^{\prime} \mathrm{S}$ & $38^{\circ} 45^{\prime} 00^{\prime \prime} \mathrm{W}$ \\
Ilhéus & Southern Coast & $15^{\circ} 40^{\prime} 38^{\prime \prime} \mathrm{S}$ & $39^{\circ} 2^{\prime} 46^{\prime \prime} \mathrm{W}$ \\
\hline
\end{tabular}

\section{Leaf sampling}

For each population of D. ecastaphyllum, 50 leaflets (10 leaflets per plants and 5 plants per area) with no pest incidence, disease attacks or wind damages were sampled. All leaflets were sampled from the middle third of branches, with a distance of approximately $5 \mathrm{~m}$ between plants. This distance was established to ensure that the plants of interest were not close to each other and to reduce the possibility of repeating the sampling in the same individual. Exsiccates were identified and deposed at the HURB herbarium of the Federal University of the Reconcavo of Bahia (UFRB, in Portuguese).

\section{Sample preparation}

The abaxial surface of leaves was scanned and measured through a scale (HP Deskjet F2050), according to the method of Vieira et al. (2014). Then, the images were converted into TPS format using the software tpsUtil (ROHFL, 2010).

After conversions, landmarks of 200 images were defined through the software tpsDig2 (ROHFL, 2010). We used 16 landmarks and semilandmarks to perform the morphometric analysis (Figure 1). These landmarks were chosen based on the position of main and secondary veins of leaves, according to Vieira et al. (2014). 


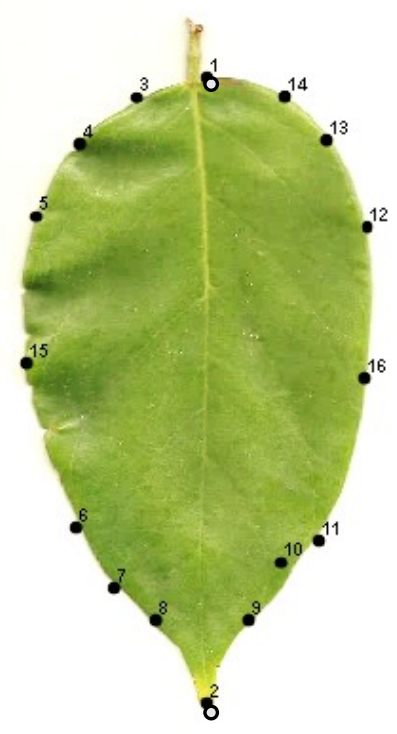

Figure 1. Landmarks (1-2) and semilandmarks (3-16) in Dalbergia ecastaphyllum leaflets.

The landmarks 1 and 2 represent the position of the main vein, which follows an easily identifiable pattern. A landmark must have in its location a homologous trait that can be recognized in each sample (WEBSTER; SHEETS, 2010). The semilandmarks 3-4, 7-8, 9-10, and 13-14 represent changes in distal and proximal regions of the leaf edge in relation to the petiole, with the location of secondary veins as standard, although impossible in some samples because their number is variable. Silva et al. (2012) emphasized that the comparison of secondary veins in leaves is difficult in case of a lack of ontogenic studies regarding the species under study. In this sense, it includes Dalbergia ecastaphyllum, no studies have been registered for this species until this moment. The semilandmarks $5-6,11-12$, and 15-16 determine the angle of curvature formed in the leaf central region intercepting secondary veins.

Landmarks 1 and 2 represent the main vein position, which follows an easily identifiable pattern. A landmark must have in its location a homologous trait that can be recognized in each sample (WEBSTER; SHEETS, 2010). Semilandmarks 3-4, 7-8, 9-10, and 13-14 represent changes in distal and proximal regions of the leaf edge in relation to the petiole, with the location of secondary veins as standard, although impossible in some samples because their number is variable. Silva et al. (2012) emphasized that the comparison of secondary veins in leaves is difficult due to the lack of ontogenic studies regarding the species under study. To date, no studies have been registered for Dalbergia ecastaphyllum. Semilandmarks 5-6, 11-12, and 15-16 determine the angle of curvature formed in the leaf central region intercepting secondary veins.
The number of semilandmarks chosen for this study was defined to represent the leaflet of $D$. ecastaphyllum as much as possible during morphometric measurements of shape. The number of semilandmarks to be determined in a study depends on the complexity of curves or surfaces and the spatial scale of the object of interest (GUNZ; MITTEROECKER, 2013). Semilandmarks were aligned using the software tps-Relw (ROHFL, 2010).

\section{Statistical analysis}

The principal component analysis (PCA) was performed for checking the total leaf shape variation in $D$. ecastaphyllum and obtaining thin plate-splines with variation trends for each principal component. The canonical variate analysis (CVA) was also performed to determine significant differences between the populations under study. The CVA determines whether predefined groups during analysis can be statistically distinguished based on multivariate data (WEBSTER; SHEETS, 2010). The representation of diagrams (Procrustes and Mahalanobis) was used to show patterns of morphological similarity between groups. The cross-validation test (permutation test with 10,000 rounds) was performed to evaluate the classification accuracy based on Mahalanobis distances. All analyses were performed using the software MorphoJ (KLINGENBERG, 2011).

The non-parametric multivariate analysis of variance (NPMANOVA) was used to determine statistical significances $(p \leq 0.05)$, while The Mentel test was performed to evaluate the correlation between populations, geographic distances, and altitudes $(p \leq 0.05)$ using, the software PAST (HAMMER et al., 2001). 


\section{RESULTS AND DISCUSSION}

In D. ecastaphyllum populations, the PCA indicated that the first four components were responsible for $97.81 \%$ of the variation in leaf shape in plants from different locations. The principal component 1 (PC 1) was $62.59 \%$, explaining more than half of all shape variation. The PC 1 represents changes in distal and proximal extremities, when positive or negative, respectively, conferring an ovate shape to the object (Figure 2). Similar to Viscosi (2015), in your study, the dominance of a component indicates that most shape variations are
MORAIS, D. V. et al.

concentrated in a single dimension, due to the evolutive process, once it leads to phenotypic characteristic.

The PC 2 was responsible for $21.97 \%$ of the variation and showed a contraction of leaves more targeted towards width-related changes, conferring an elliptical shape on the negative axis. The PCs 3 and 4 (11.44 and $1.82 \%$, respectively) refer to non-asymmetric shape patterns. Positive values on the PC 3 tended to an extension of the apical region. In the PC 4, positive values tend to more pronounced changes in the proximal region (Figure 3).
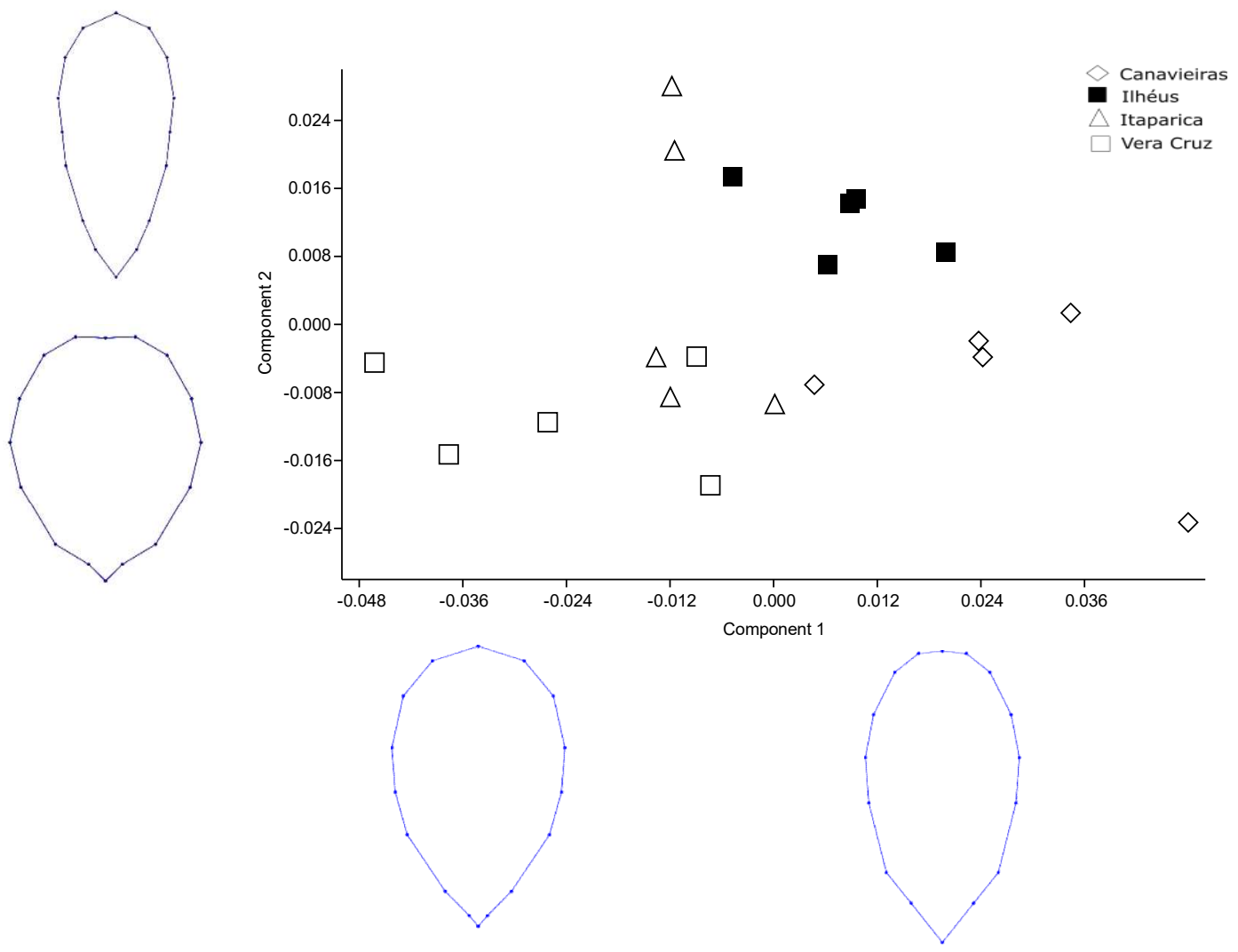

Figure 2. The principal component analysis (PCA) in the leaf shape of four populations of Dalbergia ecastaphyllum. Axis of components 1 and 2 ( $\mathrm{PC} 1$ and $\mathrm{PC} 2$ ), using a matrix of landmark coordinates aligned through the Procrustes method and the change wireframe in leaf shapes. 


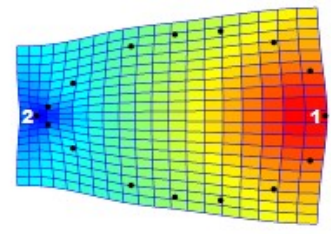

PC 1
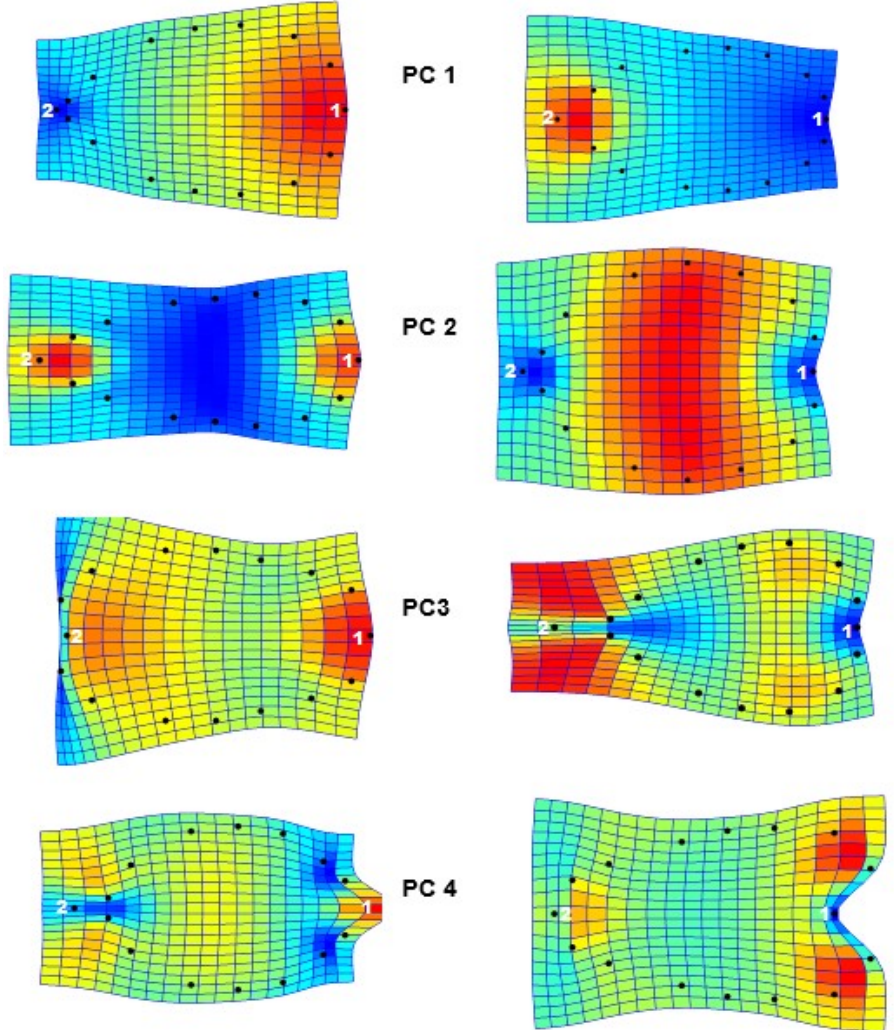

Figure 3. Thin plate-splines of Dalbergia ecastaphyllum leaves represented by four principal components. Red represents expansion; green represents distortion; and blue represents contraction. On the left, negative values of PCs and on the right, positive ones.

The PCA results indicated a natural population separation and originating some isolated groups. The PCA is capable of reducing a large number of variables in a few dimensions representing most variations in the dataset under analysis. Besides, the PCA is fast and appropriate for exploring information. The PCA is not considered a statistical test; nevertheless, it contributes to the search for sorting data with no need for prior factor to test hypothesis (MONTEIRO; REIS, 1999; MITTEROECKER; GUNZ, 2009; WEBSTER; SHEETS, 2010; FORNEL; CORDEIRO-ESTRELA, 2012).
The NPMANOVA results showed significance between population averages using the Euclidean distance (permutation value $=9.999$, total sum of squares $=0.01639$, sum of squares within groups $=0.006089, \mathrm{~F}=9.023, \mathrm{P}=0.0001$ ), in which Itaparica differed from Canavieiras and Ilhéus, while Vera Cruz only differed from Ilhéus (Table 2). Although located in different regions, the populations of Vera Cruz and Canavieiras were not significantly different, indicating that their leaf shape patterns are similar, which has great importance for the recognition of D. ecastaphyllum in the field.

Table 2. Non-parametric multivariate analysis of variance (NPMANOVA) in the leaf shape of four Dalbergia ecastaphyllum populations.

\begin{tabular}{lllll}
\hline & Itaparica & Vera Cruz & Canavieiras & Ilhéus \\
\hline Itaparica & & & & \\
Vera Cruz & 0.0558 & & & \\
Canavieiras & $0.0432^{*}$ & 0.0504 & & \\
Ilhéus & $0.0468^{*}$ & $0.0492^{*}$ & 0.1086 & \\
\hline
\end{tabular}

* Averages showing significant difference ( $p \leq 0.05)$. 
Located in the Metropolitan Region of Salvador, the municipalities of Vera Cruz and Itaparica are under the same climate and soil conditions. Furthermore, both are bounded by areas on beach edges and mainly mangrove forest. Dalbergia ecastaphyllum populations of Ilhéus and Canavieiras are located on the southern coast. Despite belonging to the same biome (Atlantic Rainforest), both municipalities are located on beach edges and hypersaline tidal flats ("apicuns"). The differences between populations are attributed to their environment, mainly regarding the phenotypic plasticity. According to Palmer et al. (2012), plasticity results in rather notable typical differences between plant species.

Huang and Liu (2014) stated that variation in shape and interspecific differences observed in Sagittaria (Alismataceae) were related to environmental conditions. Viscosi (2015) reported that the symmetrical leaf traits of Quercus frainetto Ten., Q. petraea (Matt.) Liebl, and Q. pubescens Willd might be related to hereditary factors. Furthermore, asymmetric variability might be associated with effects of fluctuating asymmetry, with no genetic influence.

Temperature and light have great importance among the abiotic factors that affect leaf shape. These factors can influence leaf growth and shape due to their tendency to oscillation (WALTER; SCHURR, 2005), acting as signals in the expression of genes involved at the beginning of leaf formation in the meristematic stem region, as well as in leaf growth, expansion, and maturity. Furthermore, $\mathrm{CO}_{2}$ concentration, altitude, and herbivory can also influence leaf shape (DKHAR; PAREEK, 2014).

Since $D$. ecastaphyllum has a rather variable vegetative habit shrubby-to-sapling, scandent or semi-prostrated it can present changes in its leaf structures, because luminosity received by plants may vary. According to Tsukaya (2004), differences in light intensity in plants lead to several leaf shapes. The author reported that low light intensity induces petiole elongation with leaf edge reduction, while high light intensity results in leaf edge expansion, inhibiting petiole elongation.

The Mahalanobis and Procrustes distance analysis (Table 3) showed the highest difference between populations of Ilhéus and Itaparica. The highest morphological proximity was observed between Ilhéus and Canavieiras, both with 14.4420. These areas are geographically close to each other $(4 \mathrm{~km})$ and present a similar climate and relief, corroborating the results in Figure 2.

Table 3. The Mahalanobis (bottom half) and Procrustes (upper half) distances obtained through the canonical variate analysis (CVA) between populations of Dalbergia ecastaphyllum.

\begin{tabular}{lllll}
\hline & Itaparica & Vera Cruz & Canavieiras & Ilhéus \\
\hline Itaparica & & 0.0404 & 0.0406 & 0.0255 \\
Vera Cruz & 14.6642 & & 0.0527 & $0.0406^{*}$ \\
Canavieiras & 16.2456 & 17.5693 & & 0.0280 \\
Ilhéus & 26.5958 & 20.6145 & 14.4420 & \\
\hline
\end{tabular}

* Averages showing significant difference $(p \leq 0.05)$

No correlation between shape, geographic distance, and altitude were observed. The correlation coefficient between shape and geographic distance was $\mathrm{r}=0.7245(p=0.1240)$. Between shape and altitude, the correlation coefficient was $\mathrm{r}=0.4009(p=0.2092)$, as expected, once the plants were sampled in mangroves and beaches at sea level, whose minimum and maximum altitudes were $4.6 \mathrm{~m}$ and $15.2 \mathrm{~m}$.

According to the CVA, the first two canonical variables represented $96.77 \%$ of total variation; therefore the first variable was responsible for $70.87 \%$ and the second, for $25.90 \%$ (Figure 4).
The CVA describes differences between previously determined groups in a set of multivariate data for investigating the magnitude ratio of differences between groups in comparison to within groups (MONTEIRO; REIS, 1999).

The cross-validation test between populations indicated an average of $83.33 \%$ proper identification, a high value, ensuring thus reliability in the separation of groups formed from leaf shape. This analysis is useful to check data efficiency and proper classification of specimens in their respective groups (FRANCOY; IMPERATRIZ-FONSECA, 2010). 


\footnotetext{
Leaf geometric...
}

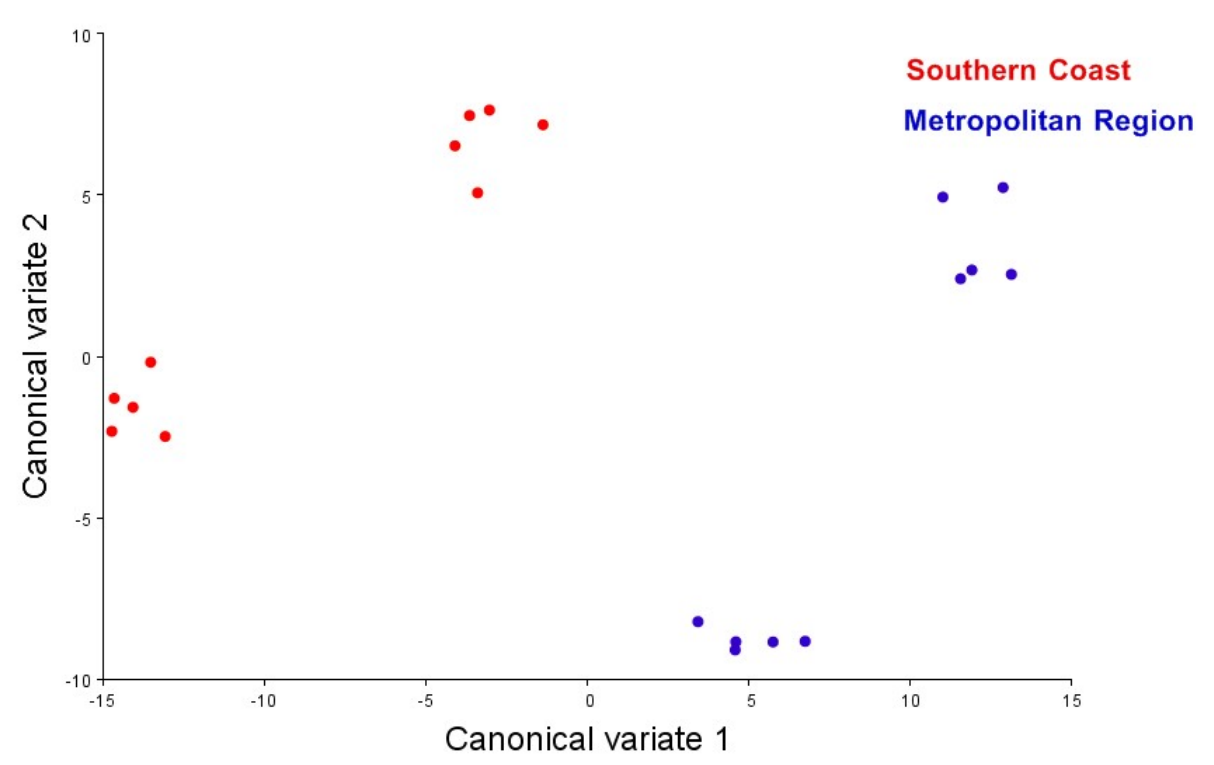

Figure 4. G

established by canonical variables (VC1, VC2) obtained from leaf shape.

\section{CONCLUSION}

The D. ecastaphyllum populations were discriminated from geographic traits, indicating the existence of morphological diversity, with two types of leaf shape: elliptical, with the widest axis part in the middle fifth of the leaf long axis and ovate, characterized by leaves with a rounded base and obtuse apex.

\section{ACKNOWLEDGMENT}

We thank the National Council of Technological and Scientific Development (Conselho Nacional de Desenvolvimento Cientifico e Tecnológico - CNPq) (156870/2014-2 to D.M.V. and 305228/2013-7 to C.A.L.C.), the Coordination for the Improvement of Higher Education Personnel (Coordenação de Aperfeiçoamento de Pessoal de Nivel Superior - CAPES) (88881.062167/2014-01) and State of Bahia Research Foundation (Fundação de Amparo a Pesquisa do Estado da Bahia FAPESB) (PET0022/2012).

RESUMO: As folhas são estruturas presentes nas plantas que expressam importantes características de acordo com o ambiente no qual estão inseridas. Ao longo dos anos, a sua caracterização tem permitido identificar espécies vegetais e correlacionar o efeito de fatores abióticos como gases, luz, temperatura e herbivoria sob o seu desenvolvimento. O presente estudo teve como descrever populações de Dalbergia ecastaphyllum do Brasil utilizando a morfometria geométrica foliar. Foram avaliadas 200 folhas de quatro populações desta espécie. Análise de componentes principais (ACP) mostrou que os quatro primeiros componentes principais explicaram 97,81\% da variação. A Análise de variância multivariada com teste nãoparamétrico (NPMANOVA) indicou não haver diferença entres as amostras $(\mathrm{p}=0,0001)$. Os resultados do teste de Mentel mostraram que não houve correlação das distâncias geográficas com a forma. Na análise de variação canônica, as duas primeiras variáveis responderam por 96,77 \% da variação total, enquanto uma média de $83,33 \%$ foi encontrada pelo teste de validação cruzada. As folhas de D. ecastaphullym são elípticas e ovadas.

PALAVRAS CHAVES: Forma. Dalbergia ecastaphyllum. Variação morfométrica. Fabaceae.

\section{REFERENCES}


BOEGER, M. R. T.; GLUZEZAK, R. M.; PIL, M. W.; GOLDENBERG, R.; MEDRI, M. Variabilidade morfológica foliar de Miconia sellowiana (DC.) Naudin (Melastomataceae) em diferentes fitofisionomias no Estado do Paraná. Revista Brasileira de Botânica, v. 31, n. 3, p. 443-452, 2008. https://doi.org/10.1590/S0100-84042008000300008

BOOKSTEIN, F. L.; MAHANEY, M. Morphometric Tools for Landmark Data: Geometry and Biology. Human Biology, v. 66, n. 1, p. 157-159, 1994.

CARVALHO, A.E.M. A synopsis of the genus Dalbergia (Fabaceae: Dalbergieae) in Brazil. Brittonia, v. 49, p. $87-109,1997$. https://doi.org/10.2307/2807701

CASTRO, M. L.; DO NASCIMENTO, A. M.; IKEGAKI, M.; COSTA-NETO, C. M.; ALENCAR, S. M.; ROSALEN, P. L. Identification of a bioactive compound isolated from Brazilian propolis type 6 . Bioorganic \& medicinal chemistry, v. 17, n. 14, p. 5332-5335, 2009. https://doi.org/10.1016/j.bmc.2009.04.066

CONESA, M. A.; MUS, M.; ROSSELLO, J. A. Leaf shape variation and taxonomic boundaries in two sympatric rupicolous species of Helichrysum (Asteraceae: Gnaphalieae), assessed by linear measurements and geometric morphometry. Biological journal of the Linnean Society, v. 106, n. 3, p. 498-513, 2012. https://doi.org/10.1111/j.1095-8312.2012.01889.x

DRYDEN, I.L., \& MARDIA, K.V. Statistical Shape Analysis: With Applications in R. John Wiley \& Sons, 2016. https://doi.org/10.1002/9781119072492

DKHAR, JEREMY; PAREEK, ASHWANI. What determines a leaf's shape?. EvoDevo, v. 5, n. 1, p. 47, 2014. https://doi.org/10.1186/2041-9139-5-47

FORNEL, R.; CORDEIRO-ESTRELA, P. Morfometria geométrica e a quantificação da forma dos organismos. Marinho, JR; Hepp, LU, Fornel, R. Temas em Biologia. Erechim, Edifapes, p. 101-120, 2012.

FRANCOY, T. M.; IMPERATRIZ-FONSECA, V. L. A morfometria geométrica de asas e a identificação automática de espécies de abelhas. Oecologia Australis, v. 14, n. 1, p. 317-321, 2017.

https://doi.org/10.4257/oeco.2010.1401.20

FROZZA, C. O. DA SILVA; GARCIA, C. S. C.; GAMBATO, G.; DE SOUZA, M. D. O.; SALVADOR, M.; MOURA, S., ... \& DELLAGOSTIN, O. A. Chemical characterization, antioxidant and cytotoxic activities of Brazilian red propolis. Food and Chemical Toxicology, v. 52, p. 137-142, 2013.

https://doi.org/10.1016/j.fct.2012.11.013

GUNZ, P.; MITTEROECKER, P. Semilandmarks: a method for quantifying curves and surfaces. Hystrix, the Italian Journal of Mammalogy, v. 24, n. 1, p. 103-109, 2013.

GÜTTLER, F.; PLÁCIDO, A. P. D. F.; AYALA, L. Comportamento morfológico da praia do rio das Pacas, Florianópolis-SC-Brasil. Percursos, v. 8, n. 2, p. 72-89, 2007.

HAMMER, Ø.; HARPER, D. A. T.; RYAN, P. D. Paleontological statistics software: Package for education and data analysis. Palaeontologia Electronica, n. 4, 2001.

HUANG, L.; LIU, YAN-CHENG. Understanding diversity in leaf shape of Chinese Sagittaria (Alismataceae) by geometric tools. Pak. J. Bot, v. 46, n. 6, p. 1927-1934, 2014.

KLINGENBERG, C. P. MorphoJ: an integrated software package for geometric morphometrics. Molecular ecology resources, v. 11, n. 2, p. 353-357, 2011. https://doi.org/10.1111/j.1755-0998.2010.02924.x 
KLINGENBERG, C. P.; DUTTKE, S.; WHELAN, S.; KIM, M. Developmental plasticity, morphological variation and evolvability: a multilevel analysis of morphometric integration in the shape of compound leaves. Journal of evolutionary biology, v. 25, n. 1, p. 115-129, 2012. https://doi.org/10.1111/j.14209101.2011.02410.x

LIMA, H.C. Fabaceae in Lista de Espécies da Flora do Brasil. Jardim Botânico do Rio de Janeiro. Disponível em: http://http://floradobrasil.jbrj.gov.br/jabot/FichaPublicaTaxonUC/FichaPublicaTaxonUC.do?id=FB83014. Acesso em: 28 ago. 2017.

MARQUES, M. C. M.; OLIVEIRA, P. E. A. M. Características reprodutivas das espécies vegetais da planície costeira. História natural e conservação da Ilha do Mel. Editora UFPR, 2005.

MDA. Plano Territorial de Desenvolvimento Sustentável Litoral Sul. 2010. Disponível em: http://sit.mda.gov.br/download/ptdrs/ptdrs_qua_territorio090.pdf. Acesso em: 28 ago. 2017.

MITTEROECKER, P.; GUNZ, P. Evolutionary Biology, v. 36, n. 2, p. 235-247, 2009.

https://doi.org/10.1007/s11692-009-9055-x

MONTEIRO, L. R.; REIS, S. F.D.. Princípios de morfometria geométrica. Holos, 1999.

OLIVEIRA, J. A. B.; DE ALMEIDA CORTEZ, J. S. Herbivoria em Dalbergia ecastophyllum em área de restinga do Norte de Pernambuco, Brasil. 2015.

PALMER, C. M.; BUSH, S. M.; MALOOF, J. N. Phenotypic and developmental plasticity in plants. eLS, 2012. https://doi.org/10.1002/9780470015902.a0002092.pub2

PIRES, M. F.; PEREIRA, M. P.; CASTRO, E. M. D;, BARBOSA, S.; PEREIRA, F. J. Micromorfometria foliar de Schinus molle L.(Anarcadiaceae) em diferentes alturas na copa. Cerne, v. 21, n. 1, 2015.

https://doi.org/10.1590/01047760201521011530

REYS, O. J.; CANTILLO, F. A. Fitocenosis presentes en las áreas costeras del sur de la sierra maestra. III. Asociación tabebuio myrtifoliae colubrinetum ellipticae. Foresta Veracruzana, v. 6, n. 2, 2004.

ROHLF, F. J. TPSDig, Digitize Landmarks and Outlines, Version 2.16. State University of New York at Stony Brook, Stony Brook. 2010.

SAVRIAMA, Y.; GÓMEZ, J. M.; PERFECTTI, F.; KLINGENBERG, C. P. Geometric morphometrics of corolla shape: dissecting components of symmetric and asymmetric variation in Erysimum mediohispanicum (Brassicaceae). New Phytologist, v. 196, n. 3, p. 945-954, 2012. https://doi.org/10.1111/j.14698137.2012.04312.x

SILVA, M. F. S.; ANDRADE, I. M.; MAYO, S. J. Geometric morphometrics of leaf blade shape in Montrichardia linifera (Araceae) populations from the Rio Parnaíba Delta, north-east Brazil. Botanical Journal of the Linnean Society, v. 170, n. 4, p. 554-572, 2012. https://doi.org/10.1111/j.10958339.2012.01309.x

STRELIN, M. M.; COSACOV, A.; DILLER, M.; SÉRSIC, A. N. Study of the polymorphism of the Patagonian Calceolaria polyrhiza (Calceolariaceae) using decision tree and sequential covering rule induction. Botanical Journal of the Linnean Society, v. 173, n. 3, p. 487-500, 2013. https://doi.org/10.1111/boj.12078

TSUKAYA, H. Leaf shape: genetic controls and environmental factors. International Journal of Developmental Biology, v. 49, n. 5-6, p. 547-555, 2004. https://doi.org/10.1387/ijdb.041921ht 
VIEIRA, M.; MAYO, S. J.; ANDRADE, I. M. Geometric morphometrics of leaves of Anacardium microcarpum Ducke and A. occidentale L.(Anacardiaceae) from the coastal region of Piauí, Brazil. Brazilian Journal of Botany, v. 37, n. 3, p. 315-327, 2014. https://doi.org/10.1007/s40415-014-0072-3

VISCOSI, V. Geometric morphometrics and leaf phenotypic plasticity: assessing fluctuating asymmetry and allometry in European white oaks (Quercus). Botanical Journal of the Linnean Society, v. 179, n. 2, p. 335 348, 2015. https://doi.org/10.1111/boj.12323

WALTER, A.; SCHURR, U. Dynamics of leaf and root growth: endogenous control versus environmental impact. Annals of botany, v. 95, n. 6, p. 891-900, 2005. https://doi.org/10.1093/aob/mci103

WEBSTER, M. A. R. K.; SHEETS, H. D. A practical introduction to landmark-based geometric morphometrics. Quantitative methods in paleobiology, v. 16, p. 168-188, 2010.

https://doi.org/10.1017/S1089332600001868 